\title{
Effects On Compressive Strength When Cement Is Partially Replaced By Fly-Ash
}

\author{
Aman Jatale ${ }^{1}$, Kartikey Tiwari ${ }^{2}$, Sahil Khandelwal ${ }^{3}$ \\ ${ }^{1,2,3}$ (Department of Civil Engineering, Sanghvi Institute of Management \& Science Behind IIM-Indore, \\ Pigdambar, 453331, Indore, India)
}

\begin{abstract}
The present paper deals with the effect on strength and mechanical properties of cement concrete by using fly ash.

The utilization of fly-ash in concrete as partial replacement of cement is gaining immense importance today, mainly on account of the improvement in the long term durability of concrete combined with ecological benefits. Technological improvements in thermal power plant operations and fly-ash collection systems have resulted in improving the consistency of fly-ash.

To study the effect of partial replacement of cement by fly-ash, studies have been conducted on concrete mixes with 300 to $500 \mathrm{~kg} / \mathrm{cum}$ cementious materials at 20\%, 40\%, 60\% replacement levels. In this paper the effect of fly-ash on workability, setting time, density, air content, compressive strength, modulus of elasticity are studied

Based on this study compressive strength $\mathrm{v} / \mathrm{s}$ W/C curves have been plotted so that concrete mix of grades M 15, M 20,M 25 with difference percentage of fly-ash can be directly designed.

Keywords- Fly Ash, Compressive Strength, Grade of Concrete.
\end{abstract}

\section{Introduction}

In the view of global warming efforts are on to reduce the emission of $\mathrm{CO}_{2}$ to the environment. Cement Industry is major in contributor in the emission of $\mathrm{CO}_{2}$ as well as using up high levels of energy resources in the production of cement. By replacing cement with a material of pozzolanic characteristic, such as the fly ash, the cement and the concrete industry together can meet the growing demand in the construction industry as well as help in reducing the environmental pollution. India is a resourceful country for fly ash generation with an annual output of over 110 millions tones, but utilization is still below $20 \%$ in spite of quantum jump in last three to four years. Availability of consistent quality fly ash across the country and awareness of positive effect of using fly ash in concrete are pre requisite for change of perception of fly ash from a waste material to a resource material.

Technological efforts have been made to improve the quality of fly ash. At present most of the power plants are using Electro Static Precipitators (ESP) through which fly ash is collected in different chambers according to its particle size. Hence uniform good quality of fly ash can be collected from these power plants.

To study the impact of partial replacement of cement by fly ash on the properties of concrete, experiments were conducted on different concrete mixes. This paper present the detailed of experimental set up and discussion on test results

\section{Green Concrete}

Engineers and architects have choices of the material and products they use to design projects when it comes to a building frame the choice is typically between concrete, steel and wood; for paving applications the choice is generally between concrete and asphalt. Material choice depends on several factors including first cost, life cycle cost and performance for a specific application. Due to growing interest in sustainable development engineers and architects are motivated more than ever before to choose materials that are more sustainable. However

this is not as straight forward as selecting an energy star rated appliance or a vehicle providing high gas mileage. 1 On what "measurement" basis can engineers and architects compare materials and choose one that is more sustainable or specify a material in such a way as to minimize environmental impact?

Life Cycle Assessment (LCA) seems to offer a solution. LCA considers materials over the course of their entire life cycle including material extraction, manufacturing, construction, operations, and finally reuse/recycling. LCA takes into account a full range of environmental impact indicators-including embodied energy, air and water pollution (including greenhouse gases), potable water consumption, solid waste and recycled content just to name a few. Building rating systems such as LEED and Green Globes are in various stages of incorporating LCA so that they can help engineers and architects select materials based on their environmental performance or specify materials in such a way as to minimize environmental impact. 
One potential drawback of LCA however is that the person conducting the analysis often has discretion to set which environmental impact indicator is most important. And often times conducting a full LCA is so complex that only a partial LCA is conducted with a focus on one or two phases of the life cycle. Recent focus on climate change and the impact of greenhouse gas emissions on our environment has caused many to focus on $\mathrm{CO} 2$ emissions as the most critical environmental impact indicator. The problem with this approach is that it forces engineers, architects and product manufacturers to focus their efforts on reducing greenhouse gas emissions without regard to other sustainable practices. Concrete and $\mathrm{CO} 2$ Every 1 ton of cement produced leads to about 0.9 tons of $\mathrm{CO} 2$ emissions and a typical cubic yard $\left(0.7643 \mathrm{~m}^{3}\right)$ of concrete contains about $10 \%$ by weight of cement.

There have been a number of articles written about reducing the $\mathrm{CO} 2$ emissions from concrete primarily through the use of lower amounts of cement and higher amounts of supplementary cementations material (SCM) such as fly ash and slag. Table 1 has been developed based on data presented by Marceau et al.5 The following observations can be made: Since a cubic yard of concrete weighs about 2 tons, CO2 emissions from 1 ton of concrete varies between 0.05 to 0.13 tons. Approximately $95 \%$ of all $\mathrm{CO} 2$ emissions from a cubic yard of concrete is from cement manufacturing and so it is no wonder that much attention is paid.

\begin{tabular}{lll}
\hline & Traditional concrete & Green concrete \\
\hline Traditional structure & $\begin{array}{l}\text { Concrete with restricted amount of } \\
\text { fly ash and micro silica }\end{array}$ & $\begin{array}{l}\text { High amount of fly ash and } \\
\text { micro silica } \\
\text { Green types of cement } \\
\text { Use of stone dust, slurry, } \\
\text { waste incineration }\end{array}$ \\
Green structure & $\begin{array}{l}\text { Green concrete (see above) } \\
\text { plus stainless steel cladding } \\
\text { or stainless steel } \\
\text { reinforcement }\end{array}$ \\
\hline
\end{tabular}

Table 4: Combination of traditional and green concrete/concrete structures

\section{FLY-ASH}

Fly ash is one of the residues generated in combustion, and comprises the fine particles that rise with the flue gases. Ash which does not rise is termed bottom ash. In an industrial context, fly ash usually refers to ash produced during combustion of coal. Fly ash is generally captured by precipitators or other particle filtration equipment before the flue gases reach the chimneys of coal-fired power plants, and together with bottom ash removed from the bottom of the furnace is in this case jointly known as coal ash. Depending upon the source and makeup of the coal being burned, the components of fly ash vary considerably, but all fly ash includes substantial amounts of silicon dioxide $\left(\mathrm{SiO}_{2}\right)$ (both amorphous and crystalline) and calcium oxide $(\mathrm{CaO})$, both being endemic ingredients in many coal-bearing rock strata.

Toxic constituents depend upon the specific coal bed makeup, but may include one or more of the following elements or substances in quantities from trace amounts to several percent: arsenic, beryllium, boron, cadmium, chromium, chromium, cobalt, lead, manganese, mercury, molybdenum, selenium, strontium, thallium, and vanadium, along with dioxins and PAH compounds.

In some cases, such as the burning of solid waste to create electricity ("resource recovery" facilities a.k.a. waste-to-energy facilities), the fly ash may contain higher levels of contaminants than the bottom ash and mixing the fly and bottom ash together brings the proportional levels of contaminants within the range to qualify as nonhazardous waste in a given state, whereas, unmixed, the fly ash would be within the range to qualify as hazardous waste.

\section{Chemical Composition}

Fly ash material solidifies while suspended in the exhaust gases and is collected by electrostatic precipitators or filter bags. Since the particles solidify rapidly while suspended in the exhaust gases, fly ash particles are generally spherical in shape and range in size from $0.5 \mu \mathrm{m}$ to $300 \mu \mathrm{m}$. The major consequence of the rapid cooling is that only few minerals will have time to crystallize and that mainly amorphous, quenched glass remains. Nevertheless, some refractory phases in the pulverized coal will not melt (entirely) and remain crystalline. In consequence, fly ash is a heterogeneous material. $\mathrm{SiO} 2, \mathrm{Al} 2 \mathrm{O} 3, \mathrm{Fe} 2 \mathrm{O} 3$ and occasionally $\mathrm{CaO}$ are the main chemical components present in fly ashes. The mineralogy of fly ashes is very diverse. The main phases encountered are a glass phase, together with quartz, mullite and the iron oxides hematite, magnetite . 


\begin{tabular}{llll}
\hline Component & Bituminous & Sub bituminous & Lignite \\
\hline $\mathrm{SiO}_{2}(\%)$ & $20-60$ & $40-60$ & $15-45$ \\
$\mathrm{Al}_{2} \mathbf{O}_{3}(\%)$ & $5-35$ & $20-30$ & $20-25$ \\
$\mathrm{Fe}_{2} \mathbf{O}_{3}(\%)$ & $10-40$ & $4-10$ & $4-15$ \\
$\mathbf{C a O}(\%)$ & $1-12$ & $5-30$ & $15-40$ \\
$\mathbf{L O I}(\%)$ & $0-15$ & $0-3$ & $0-5$ \\
\hline
\end{tabular}

Table 5:-Chemical Composition of fly ash

The above concentrations of trace elements vary according to the kind of coal combusted to form it. In fact, in the case of bituminous coal, with the notable exception of boron, trace element concentrations are generally similar to trace element concentrations in unpolluted soils.

Two classes of fly ash are defined by ASTM C618: Class F fly ash and Class C fly ash. The chief difference between these classes is the amount of calcium, silica, alumina, and iron content in the ash. The chemical properties of the fly ash are largely influenced by the chemical content of the coal burned (i.e., anthracite, bituminous, and lignite).

Not all fly ashes meet ASTM C618 requirements, although depending on the application, this may not be necessary. Ash used as a cement replacement must meet strict construction standards, but no standard environmental regulations have been established in the United States. $75 \%$ of the ash must have a fineness of $45 \mu \mathrm{m}$ or less, and have carbon content, measured by the loss on ignition (LOI), of less than $4 \%$. In the U.S., LOI needs to be fewer than $6 \%$. The particle size distribution of raw fly ash is very often fluctuating constantly, due to changing performance of the coal mills and the boiler performance. This makes it necessary that, if fly ash is used in an optimal way to replace cement in concrete production, it needs to be processed using beneficiation methods like mechanical air classification. But if fly ash is used also as a filler to replace sand in concrete production, unbeneficiated fly ash with higher LOI can be also used. Especially important is the ongoing quality verification. This is mainly expressed by quality control seals like the Bureau of Indian Standards mark or the DCL mark of the Dubai Municipality.

\section{- Class F fly ash}

\section{Types Of Fly-Ash}

The burning of harder, older anthracite and bituminous coal typically produces Class F fly ash. This fly ash is pozzolanic in nature, and contains less than $20 \%$ lime $(\mathrm{CaO})$. Possessing pozzolanic properties, the glassy silica and alumina of Class F fly ash requires a cementing agent, such as Portland cement, quicklime, or hydrated lime, with the presence of water in order to react and produce cementations compounds. Alternatively, the addition of a chemical activator such as sodium (water glass) to a Class F ash can leads to the formation of a geopolymer.

\section{- Class C fly ash}

Fly ash produced from the burning of younger lignite or sub bituminous coal, in addition to having pozzolanic properties, also has some self-cementing properties. In the presence of water, Class C fly ash will harden and gain strength over time. Class $\mathrm{C}$ fly ash generally contains more than $20 \%$ lime $(\mathrm{CaO})$. Unlike Class $\mathrm{F}$, self-cementing Class $\mathrm{C}$ fly ash does not require an activator. Alkali and sulfate (SO4) contents are generally higher in Class C fly ashes.

\begin{tabular}{lll}
\hline Properties & Description & $\begin{array}{l}\text { Requirement as } \\
\text { IS: } \mathbf{3 8 1 2 - 2 0 0 3}\end{array}$ \\
\hline Physical properties & $\begin{array}{l}\text { Fineness- } \mathrm{sp} \text {. Surface }\left(\mathrm{m}^{2} / \mathrm{kg}\right) \\
\begin{array}{l}\text { Comp. strength at } 28 \text { days as } \% \text { of cement mortar } \\
\text { cubes }\end{array}\end{array}$ & $>80$ \\
\hline $\begin{array}{l}\text { Lime reactivity }(\mathrm{MPa}) \\
\text { Drying shrinkage }\end{array}$ & $<4.0$ \\
\hline Soundness by autoclaving Expansion Method & $<0.15$ \\
\hline
\end{tabular}




\begin{tabular}{|c|c|c|}
\hline \multirow[t]{9}{*}{ Chemical properties } & Loss on ignition (\% by wt.) & $<12$ \\
\hline & Silica as $\mathrm{Sio}_{2}$ (\% by wt.) & $>35$ \\
\hline & Iron Oxide as $\mathrm{Fe}_{2} \mathrm{O}_{3}(\%$ by wt. $)$ & --- \\
\hline & Alumina as $\mathrm{Al}_{2} \mathrm{O}_{3}(\%$ by wt. $)$ & --- \\
\hline & Total of $\mathrm{SiO}_{2}, \mathrm{Fe}_{2} \mathrm{O}_{3}, \mathrm{Al}_{2} \mathrm{O}_{3}$ (\% by wt.) & $>70$ \\
\hline & Calcium Oxide $\mathrm{CaO}$ (\% by wt.) & --- \\
\hline & Magnesium Oxide $\mathrm{MgO}$ (\% by wt.) & $<5.0$ \\
\hline & Sulfur as $\mathrm{SO}_{3}(\%$ by wt.) & $<2.75$ \\
\hline & Alkalies (\% by wt.) Sodium Oxide & $<1.50$ \\
\hline
\end{tabular}

\section{Table 6:- Properties of fly ash}

\section{REUSE}

The ways of fly ash utilization include (approximately in order of decreasing importance):

- Concrete production, as a substitute material for Portland cement and sand

- Embankments and other structural fills (usually for road construction)

- Grout and Flowable fill production

- Waste stabilization and solidification

- Cement clinkers production - (as a substitute material for clay)

- Mine reclamation

- Stabilization of soft soils

- Road sub base construction

- As Aggregate substitute material (e.g. for brick production)

- Mineral filler in asphaltic concrete

- Agricultural uses: soil amendment, fertilizer, cattle feeders, soil stabilization in stock feed yards, and agricultural stakes

- Loose application on rivers to melt ice

- Loose application on roads and parking lots for ice control

Other applications include cosmetics, toothpaste, kitchen counter tops, floor and ceiling tiles, bowling balls, flotation devices, stucco, utensils, tool handles, picture frames, auto bodies and boat hulls, cellular concrete, geopolymers, roofing tiles, roofing granules, decking, fireplace mantles, cinder block, PVC pipe, Structural Insulated Panels, house siding and trim, running tracks, blasting grit, recycled plastic lumber, utility poles and cross arms, railway sleepers, highway sound barriers, marine pilings, doors, window frames, scaffolding, sign posts, crypts, columns, railroad ties, vinyl flooring, paving stones, shower stalls, garage doors, park benches, landscape timbers, planters, pallet blocks, molding, mail boxes, artificial reef, binding agent, paints and undercoating's, metal castings, and filler in wood and plastic products.

\section{VIII.1. Experimental Setup}

\section{Methodology}

High range super plasticizer was used in all the concrete mixes to achieve good workability. A slump of $200 \mathrm{~mm}+\mathrm{mm}$ was maintained in all the mixes to ensure that this mixes could be pumped and placed even in the most congested areas. Unit water content was kept constant for a particular series of mixes of same cementitious content. To achieve the uniform workability, the admixture dosage was adjusted without changing the unit water content this ensured the identical $\mathrm{w} / \mathrm{cm}$ ratio for a particular cementitious content and the effect of fly ash replacement can be directly studied on various properties of concrete.

\section{VIII.2 Ingredients Cement}

The ordinary Portland cement conforming to IS: 8112 was used. The specific surface of cement used in this study was $60 \mathrm{~N} / \mathrm{mm}^{2}$ and $295 \mathrm{~m}^{2} / \mathrm{kg}$ respectively. 


\section{Coarse Aggregate}

The coarse aggregate from crushed basalt rock, conforming to IS: 383 were used. The flakiness and elongation index were maintained well below $15 \%$.

\section{Fine Aggregate}

The river sand and crushed sand was used in combination as fine aggregate conforming to the requirements of IS: 383 . The river sand was washed and screened, to eliminate deleterious material and over size particle.

\section{Admixture}

The high range water reducing and retarding super plasticizer conforming to ASTM C-494,

Type $G$ was used. The base of admixture used in this study was sulphonated naphthalene formaldehyde and water reduction of admixture was around $20 \%$.

\section{VIIII. Experimental Programm}

The test performed for testing the Compressive strength of concrete using fly ash. Various cubes are made with various percentage of fly ash by weight of cement, tested and then analyzed for finding the effect of using fly ash.

Three concrete cube specimens for the test is made for each M-15, M-20 and M-25 with 20\%, 40\% and 60\% fly ash composition.

Compressive strength test is the most common test conducted on hardened concrete as it is an easy test to perform and also most of the desirable characteristic properties of concrete are qualitatively related to its compressive strength. The compression test is carried out on specimen cubical in shape .Prism is also sometimes used, but it is not common in our country. Sometimes, the compressive strength of concrete is determined using the parts of beam tested in flexure.

The cube specimen is of size $150 * 150 * 150 \mathrm{~mm}$.If the largest size of aggregate does not exceed $20 \mathrm{~mm}, 100 \mathrm{~mm}$ size cubes may also be used as an alternative.

\section{Procedure}

- First of all the mould preferably of cast iron, thick enough to prevent distortion, is used to prepare the specimen of size $150 * 150 * 150 \mathrm{~mm}$.

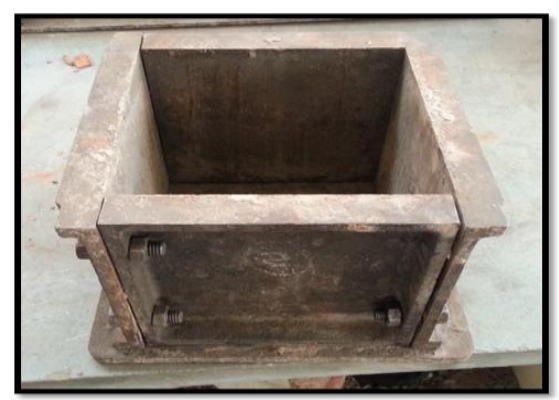

Fig 9:- Cube Mould.

- During the placing of concrete in the moulds it is compacted with the tamping bar $16 \mathrm{~mm}$ diameter, $0.6 \mathrm{~mm}$ long and bullet pointed at lower end, with not less than 25 strokes per layer.

- Then these moulds are placed on the vibrating table (fig.10) and are compacted until the specified condition is attained.

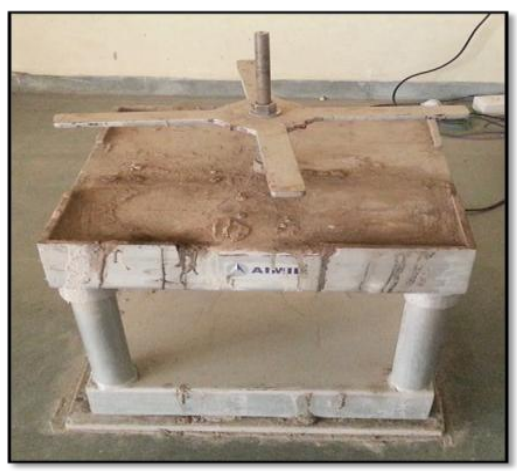

Fig 10:- Vibrating Table 
- The test specimens are stored in place free from vibration, in moist air of at least $90 \%$ relative humidity and at a temperature of 27 degree +_2degree $\mathrm{C}$ for $24 \mathrm{hrs}$ from the addition of water to the dry ingredients.

- After this period, the specimen is marked and submerged water and kept there until taken out just prior to test. The water in which the specimens are submerged, are renewed every 7 days. The specimens are not to be allowed to become dry at any time until they have been tested.

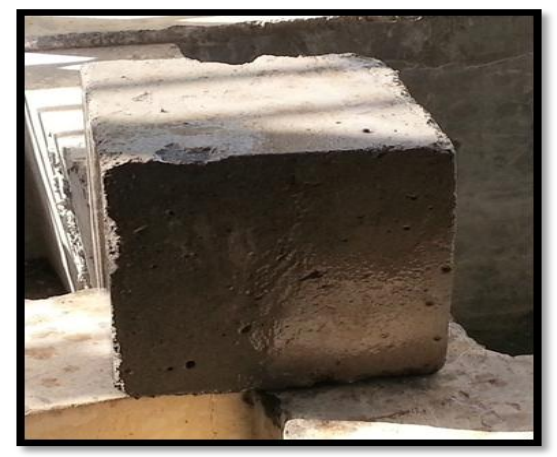

Fig 11:- Cube After 7 Days Curing.

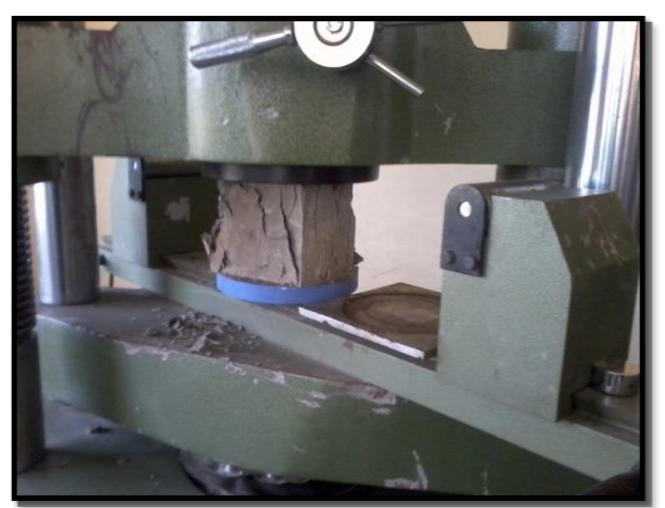

Fig 12:- UTM machine during testing.

- The cube is then taken out of the curing tank and placed in the UTM machine (fig.12) so to find the maximum load at which the concrete fails by compression.

\section{RESULTS}

The results from the compression test are in the form of the maximum load the cube can carry before it ultimately fails. The compressive stress can be found by dividing the maximum load by the area normal to it. The results of compression test and the corresponding compressive stress is shown in table

Let,

$\mathrm{F}=$ maximum load carried by the cube before failure

$\mathrm{A}=$ area normal to load $=150 \times 150 \mathrm{~mm}^{2}=22500 \mathrm{~mm}^{2}$

\section{BLOCK A}

Date of experiment

27/9/12

Grade of concrete - M15 [1:2:4]

11/10/12

Volume of concrete $=3.375 \times 10^{-3} \mathrm{~m}^{3}$

Weight $=3.375 \times 10^{-3} \times 24$

Volume of cement concrete $=0.081 \mathrm{KN}$

Volume of Concrete $=(0.081 \times 1000) / 9.81$

Volume of Concrete $=8.256 \mathrm{~kg}$

Cement $=8.256 / 7$

Cement $=1.18 \mathrm{~kg}$

$80 \%$ Cement $=0.944 \mathrm{~kg}$ 
$20 \%$ Fly ash $=0.236 \mathrm{~kg}$

Water $=0.472 \mathrm{~kg}=472 \mathrm{ml}$

Sand $=2.36 \mathrm{~kg}$

Aggregate $=4.72 \mathrm{~kg}$

After 7 day

Initial Load $=484.15 \mathrm{KN}$

Crack $=600 \mathrm{KN}$

Fail $=810 \mathrm{KN}$

Therefore,

Applied Load $=810-484.15=325.85 \mathrm{KN}$

Applied Load $=325.85 \times 10^{3} \mathrm{~N}$

Cross Sectional Area $=$ Length $\times$ Width

Area $=150 \mathrm{x} 150$

Area $=22500 \mathrm{~mm}^{2}$

Max. load carried by the cube before failure

(F)

Strength of Mould = Cross sectional Area

(A)

Strength of Mould $=\frac{325.85 \times 10^{\wedge} 3}{22500}$

Strength of mould $=14.48 \mathrm{~N} / \mathrm{mm}^{2}$

\begin{tabular}{|c|c|}
\hline $\begin{array}{c}\text { BLOCK B } \\
\text { Grade of concrete }- \text { M20 [1:1.5:3] } \\
80 \% \text { Cement }=1.8 \mathrm{~kg} \\
20 \% \text { Fly ash }=0.45 \mathrm{~kg} \\
\text { Strength of mould }=\mathbf{1 0 . 8 8 ~ N / \mathbf { m m } ^ { 2 }}\end{array}$ & $\begin{array}{l}\text { Date of experiment } 27 / 9 / 12 \\
\text { Reading date 4/10/12 }\end{array}$ \\
\hline $\begin{array}{c}\text { BLOCK C } \\
\text { Grade of concrete-M25 [1:1:2] } \\
80 \% \text { Cement }=1.65 \mathrm{~kg} \\
20 \% \text { Fly ash }=0.41 \mathrm{~kg} \\
\text { Strength of mould }=\mathbf{1 4 . 0 4 ~ N / \mathbf { m m } ^ { 2 }}\end{array}$ & $\begin{array}{c}\text { Date of experiment } 27 / 9 / 12 \\
\text { Reading date } 11 / 10 / 12\end{array}$ \\
\hline $\begin{array}{c}\text { BLOCK D } \\
\text { Grade of concrete-M15[1:2:4] } \\
60 \% \text { Cement }=0.71 \mathrm{~kg} \\
40 \% \text { Fly ash }=0.427 \mathrm{~kg} \\
\text { Strength of mould }=\mathbf{1 2 . 8 0 ~ N / \mathbf { m m } ^ { 2 }}\end{array}$ & $\begin{array}{l}\text { Date of experiment } 04 / 10 / 12 \\
\text { Reading date } 17 / 10 / 12\end{array}$ \\
\hline 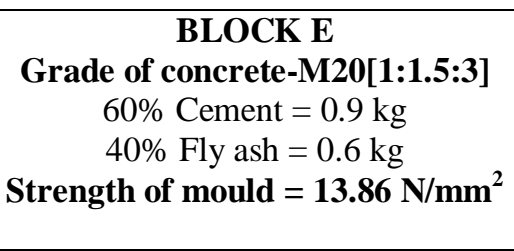 & $\begin{array}{c}\text { Date of experiment } 04 / 10 / 12 \\
\text { Reading date } 17 / 10 / 12\end{array}$ \\
\hline 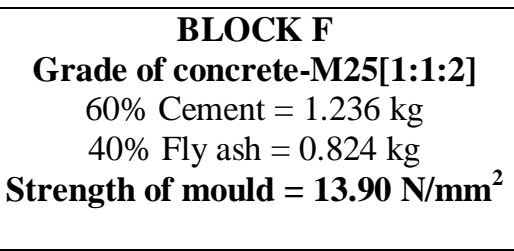 & $\begin{array}{c}\text { Date of experiment } 04 / 10 / 12 \\
\text { Reading date } 17 / 10 / 12\end{array}$ \\
\hline $\begin{array}{c}\text { BLOCK G } \\
\text { Grade of concrete-M15[1:2:4] } \\
40 \% \text { Cement }=0.472 \mathrm{~kg} \\
60 \% \text { Fly ash }=0.708 \mathrm{~kg}\end{array}$ & $\begin{array}{c}\text { Date of experiment:- 11/10/12 } \\
\text { Reading date:- 02/10/12 }\end{array}$ \\
\hline
\end{tabular}




\begin{tabular}{|c|c|}
\hline Strength of mould $=11.90 \mathrm{~N} / \mathrm{mm}^{2}$ & \\
\hline $\begin{array}{c}\text { BLOCK H } \\
\text { Grade of concrete-M20[1:1.5:3] } \\
40 \% \text { Cement }=0.6 \mathrm{~kg} \\
60 \% \text { Fly ash }=0.4 \mathrm{~kg} \\
\text { Water }=0.6 \mathrm{~kg}=600 \mathrm{ml} \\
\text { Strength of mould }=\mathbf{1 4 . 0 3 ~} \mathbf{N} / \mathbf{m m}^{2}\end{array}$ & $\begin{array}{c}\text { Date of experiment } 11 / 10 / 12 \\
\text { Reading date } 02 / 11 / 12\end{array}$ \\
\hline $\begin{array}{c}\text { BLOCK I } \\
\text { Grade of concrete-M25[1:1:2] } \\
40 \% \text { Cement }=0.824 \mathrm{~kg} \\
60 \% \text { Fly ash }=1.24 \mathrm{~kg} \\
\text { Strength of mould }=\mathbf{1 2 . 7 0 ~ N / \mathbf { m m } ^ { 2 }}\end{array}$ & $\begin{array}{c}\text { Date of experiment:- 11/10/12 } \\
\text { Reading date:- 02/10/12 }\end{array}$ \\
\hline
\end{tabular}

Table 7:- Block wise Conc. mix, \% fly Ash \& Compressive strength

\begin{tabular}{|c|c|c|c|c|c|}
\hline $\begin{array}{c}\text { Table } 8:- \\
\text { Comparative Results }\end{array}$ & & $\begin{array}{c}\text { Replacing 20\% c } \\
\text { Ash }\end{array}$ & nent Fly & $\begin{array}{l}\text { Replacing } 60 \% \text { cement } \\
\text { by Fly Ash }\end{array}$ & $\begin{array}{l}\text { Replacing } 40 \% \text { cement } \\
\text { by Fly Ash }\end{array}$ \\
\hline$\underline{\text { M15 }}$ & & 14.48 & & 13.8 & 11.9 \\
\hline$\underline{\overline{M 20}}$ & 15 & 10.88 & $20 \%$ & $13.864 .48 \mathrm{~N} / \mathrm{mm}^{2}$ & 14.03 \\
\hline M25 & & 14.04 & & 13.9 & 12.7 \\
\hline$\underline{\mathbf{C}}$ & M25 & & $20 \%$ & $14.04 \mathrm{~N} / \mathrm{mm}^{2}$ & \\
\hline$\underline{\mathbf{D}}$ & $\overline{\mathrm{M} 15}$ & & $\overline{40 \%}$ & $13.80 \mathrm{~N} / \mathrm{mm}^{2}$ & \\
\hline$\overline{\mathbf{E}}$ & $\overline{\mathrm{M} 20}$ & & $\overline{40 \%}$ & $13.86 \mathrm{~N} / \mathrm{mm}^{2}$ & \\
\hline$\overline{\mathbf{F}}$ & M25 & & $40 \%$ & $13.90 \mathrm{~N} / \mathrm{mm}^{2}$ & \\
\hline$\overline{\mathbf{G}}$ & $\overline{\mathrm{M} 15}$ & & $60 \%$ & $11.90 \mathrm{~N} / \mathrm{mm}^{2}$ & \\
\hline$\underline{\overline{\mathbf{H}}}$ & $\overline{\mathrm{M} 20}$ & & $\underline{60 \%}$ & $14.03 \mathrm{~N} / \mathrm{mm}^{2}$ & \\
\hline$\overline{\mathbf{I}}$ & $\overline{\mathrm{M} 25}$ & & $60 \%$ & $12.70 \mathrm{~N} / \mathrm{mm}^{2}$ & \\
\hline
\end{tabular}

XI. GRAPHICAL COMPARISON

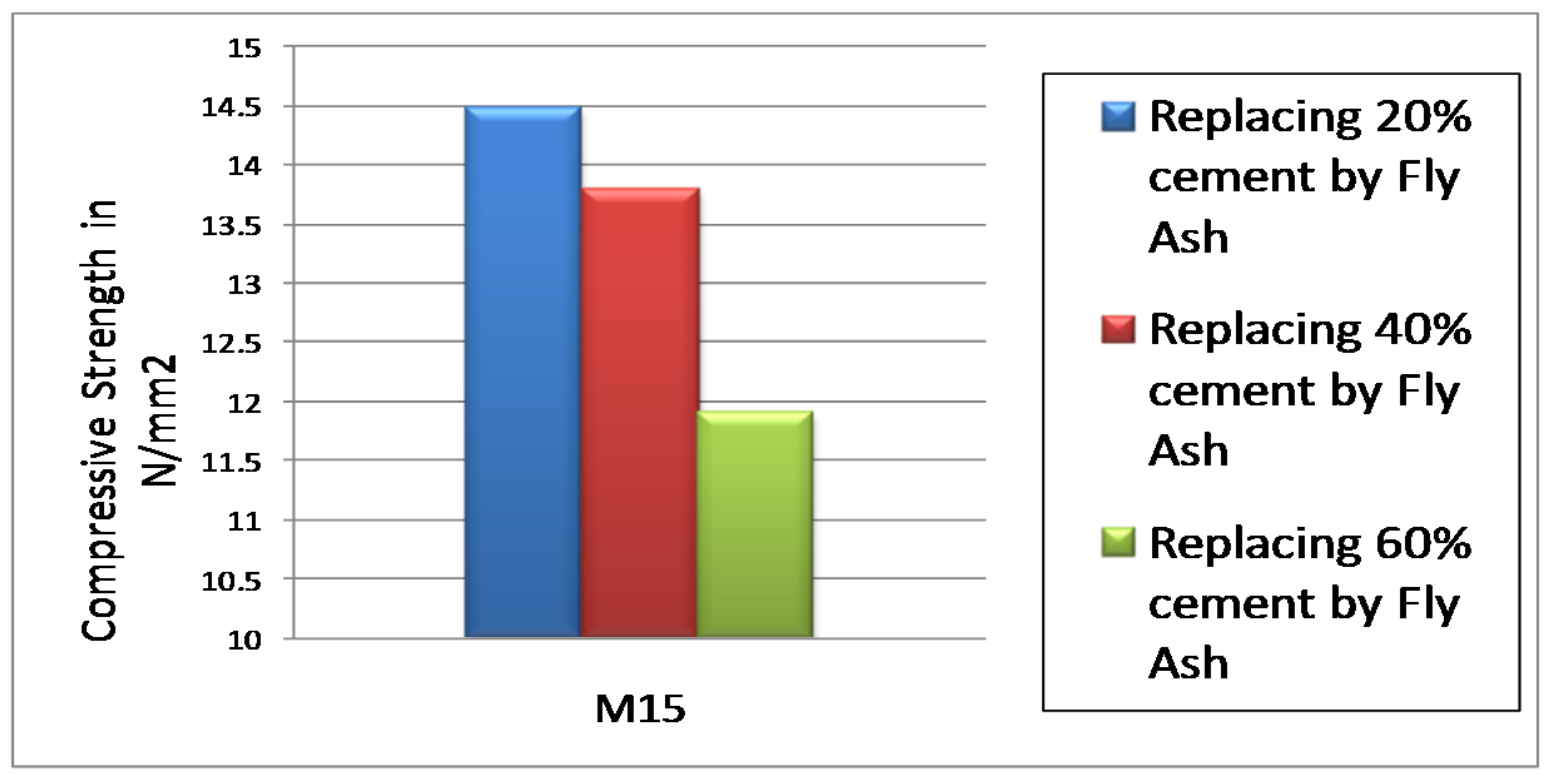

Fig 4.1 Comparison of Compressive Strength of M-15 grade of concrete with varying Percentage of Fly-Ash. 


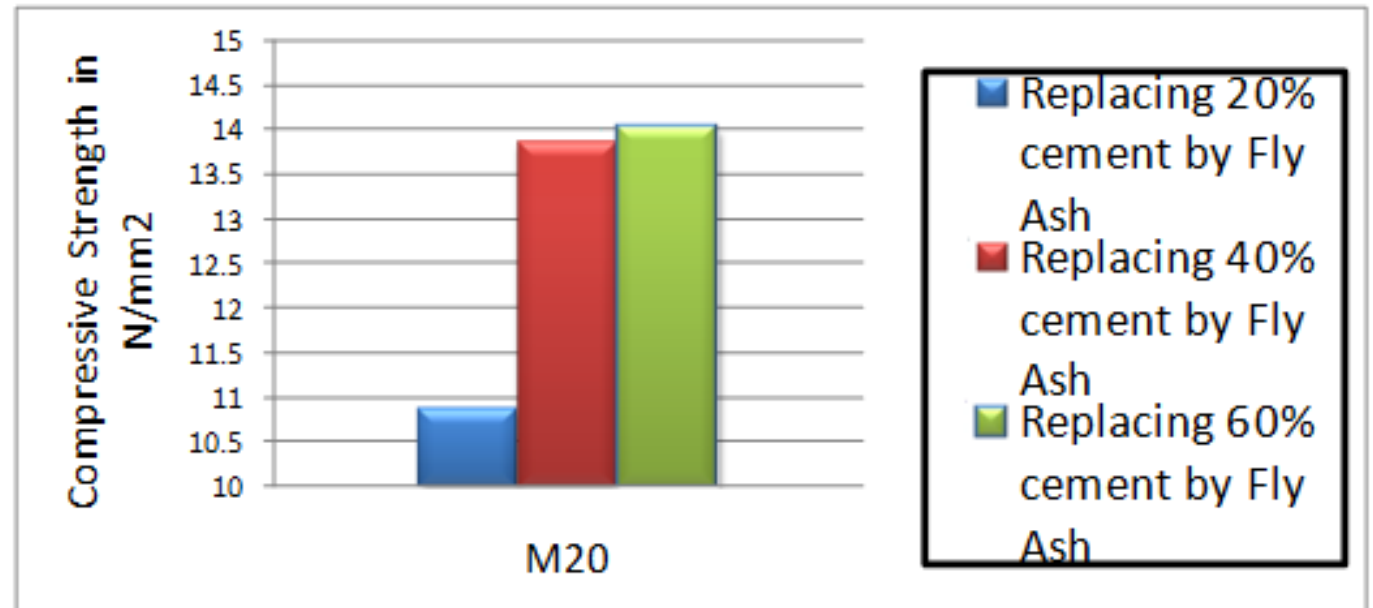

Fig 4.2 Comparison of Compressive Strength of $M$-20 grade of concrete with varying percentage of Fly-Ash

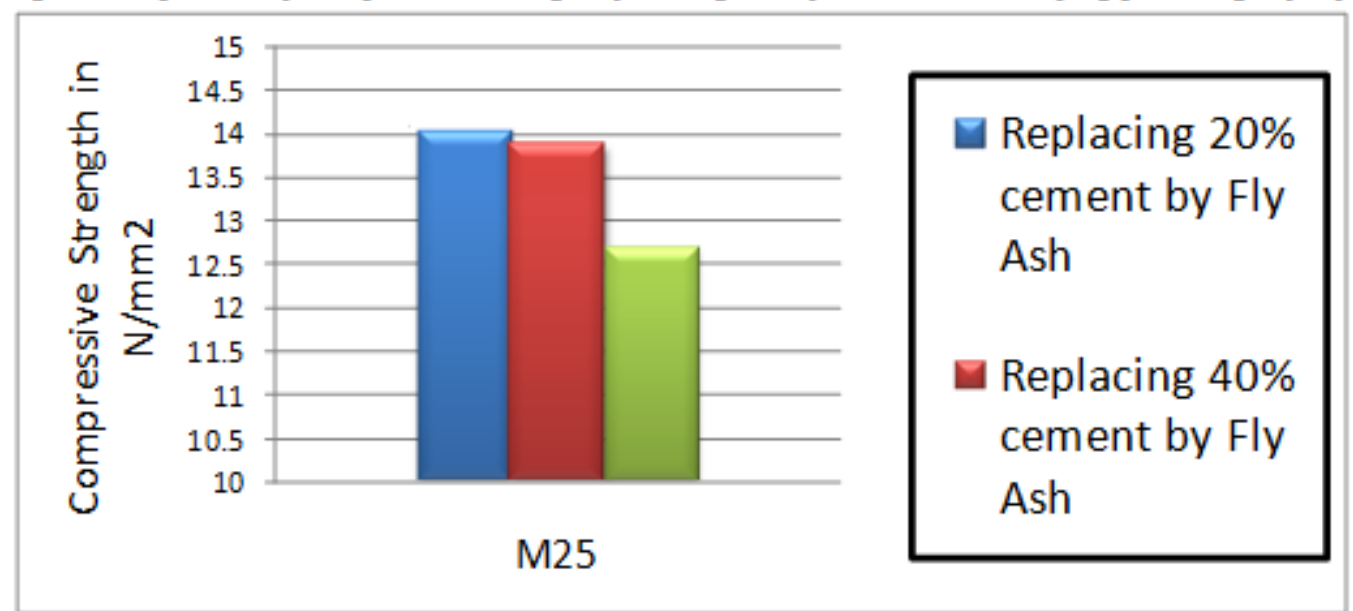

Fig 43 Conparison of Compressive Strength of M-25 grade of concrete with varjing \% of $F y$. Ash.

Fig 4.4 Comparison of Compressive Strength of different grade of concrete with varying percentage of Fly

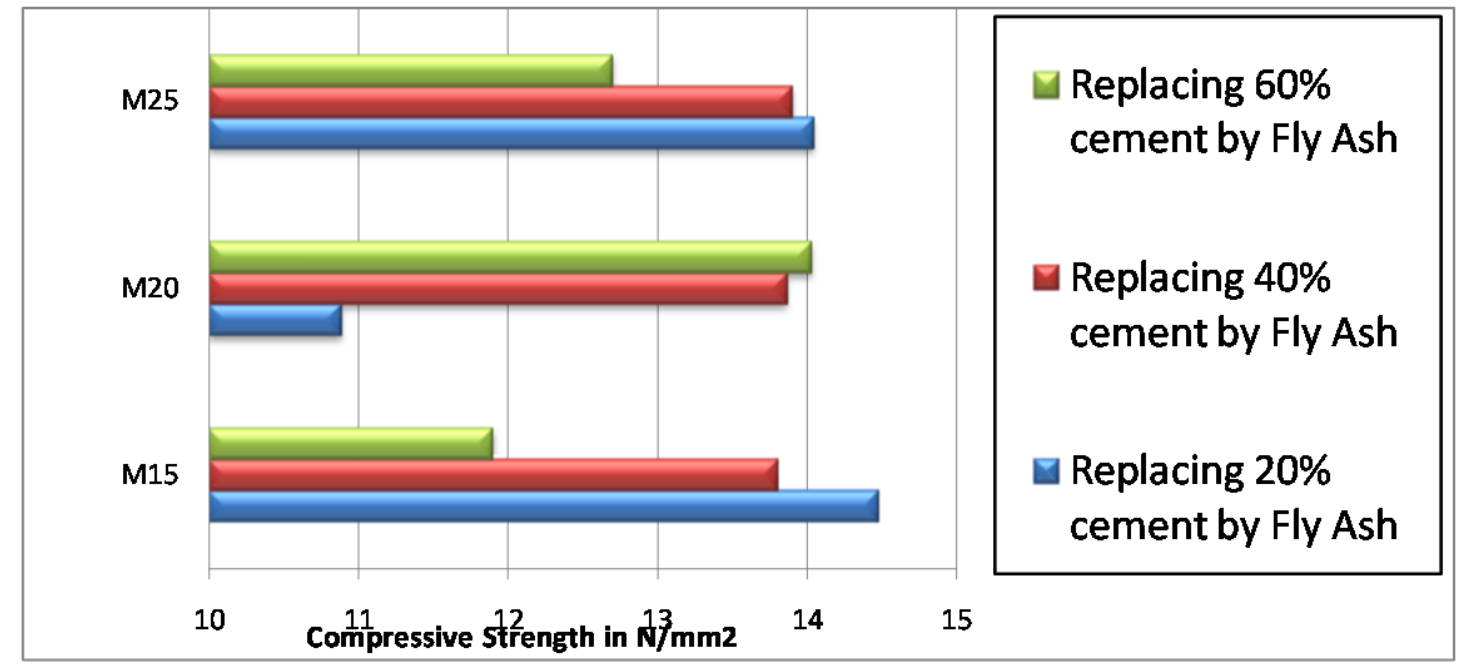

Ash. 


\section{Conclusion}

India has a vast resource of fly ash generation all across the country. This material if segregated, collected and used properly can solve the major problem can solve the major problems of fly ash disposal and reducing the use of cement, which consumes lot of energy and natural resources. Especially in India many organizations are putting their efforts to promote the awareness of fly ash concrete and its advantages. Nuclear Power Corporation of India Ltd (NPCIL) is also involved in R\&D activities for development of fly ash concrete and implementing it in construction of nuclear power structure.

The experimental exercise has helped to study the various properties of fly ash concrete and to develop the mix design curves for concrete mix proportioning with various percentages of fly ash. Based on the studies conducted by authors following conclusion are drawn on the fly ash concrete.

1. Use of fly ash improves the workability of concrete. This phenomenon can be used either the unit water content of mix or to reduce the admixture dosage.

2. Density and air content of concrete mix are generally unaffected with the use of fly ash.

3. Normally use of fly ash slightly retards the setting time of concrete, but it is compensated by reduction in the admixture dosage to maintain the same workability.

4. Bleeding in fly ash concrete is significantly reduced and other properties like cohesiveness, pumping characteristics and surface finish are improved.

5. As the fly ash content increases there is reduction in the strength of concrete. This reduction is more at earlier ages as compared to later ages. This is expected, as the secondary hydration due to pozzolanic action is slower at initial stage for fly ash concrete.

6. Rate of strength development at various ages is related to the $\mathrm{W} / \mathrm{Cm}$ and percentages of fly ash in the concrete mix.

7. Modulus of elasticity of fly ash concrete also reduces with the increase in fly ash percentage for a given $\mathrm{W} / \mathrm{Cm}$. Reduction in $\mathrm{E}$ value is much lower as compared to compressive strength.

8. Shrinkage of fly ash concrete mix is similar to control concrete mix.

9. Fly ash concrete is more durable as compare to OPC concrete. Significant reduction in RCPT values at 56 days and 90 days indicates much lower permeability of fly ash concrete as compare to OPC concrete.

The time has come for appreciating the fact without any reservation that fly ashcan be gain fully used in Making concrete strong, durable, Eco-friendly and economical.

\section{References}

\section{Journal Papers:}

[1] Vol. 3, No. 1, February 2008, Arpn Journal Of Engineering And Applied Sciences, Effect Of Concentration Of Alkaline Liquid And Curing Time On Strength And Water Absorption Of Geopolymer Concrete.

[2] Vol. 7, No. 1, January 2012, Arpn Journal Of Engineering And Applied Sciences, Recycled Aggregate Concrete Exposed To Elevated Temperature

[3] Featured at the proceedings FIB-symposium "Concrete and environment" in Berlin, October 2001, Environmentally "Green"

Books:

Concrete Structures.
Ceatured at the proceedings FIB-symposium "Concrete and environment" in Berlin, October 2001, Environmentally "Green"

[4] Rangan, B. V., Hardjto, D. 2005. Development and properties of low calcium fly ash based geopolymer concrete. Research report GC-1, Faculty of Engineering, Curtins University of Technology, and Perth, Australia.

[5] Van Jaarsveld, J. G. S., Van Deventer, J. S. J., Lorenzen, L. Factors affecting the immobilization of metals in Geopolymerized fly ash. Metallurgical and Material Transactions. B 29B (1): 283-291.

[6] M.L., Concrete Technology

[7] M.S. Shetty, Concrete Technology

[8] R.S. Khurmi

[9] IS Code 456:2000.

[10] Neville A.M. (1995), Properties of Concrete, Essex: Longman

Chapters in Books:

[11] Recommended guidelines for concrete mix design, IS 10262: 1982.Bureau of Indian Standards, New Delhi, India.

[12] ACI Committee 201. 1989. Guide to durable concrete. American Concrete Institute.

[13] Specification for fly ash for use as pozzolona and admixture IS 3812: 1981.Bureau of Indian Standards, New Delhi, India.

[14] Specification for Coarse \& Fine Aggregates from Natural Sources for Concrete ( ${ }^{\text {nd }}$ Revision). IS:383: 1970, BIS, New Delhi.

[15] Specification for 53 grade ordinary Portland cement, IS 12269:1987, Bureau of Indian Standards, New Delhi, India.

Theses:

[16] Applied Research Paper: Autoclaved Aerated Concrete as a Green Building Material Stefan Schnitzler October 2006. 